øvrig er det lite som tyder på at den «avdankede» filosofen Michel Foucaults (1926-1984) maktkritikk ikke er relevant for dagens psykiatridebatt.

\section{Ketil Slagstad}

ketil.slagstad@tidsskriftet.no

Ketil Slagstad (f. 1983) er medisinsk redaktør i Tidsskriftet.

Ingen oppgitte interessekonflikter.

\section{Re: Psykiatriens indre konflikter eksponert}

Medisinsk redaktør Ketil Slagstad anfører at effekten av antipsykotika er omdiskutert. Jeg ønsker kort å kommentere dette punktet. Nyere metaanalyser viser at effektstørrelsen av antipsykotika sammenlignet med placebo ved akuttbehandling av schizofreni er om lag 0,5 for samlet symptomreduksjon, med variasjoner mellom $0,3 \mathrm{og}$ 0,9 for ulike antipsykotika (1). Leucht og medarbeidere (2) har sammenlignet effektstørrelser av vanlige legemiddelgrupper innen generell medisin, med effektstørrelsene av psykofarmaka. Konklusjonen er at effektstørrelsen for antipsykotika er fullt på høyde med effektstørrelsen for en rekke andre medikamentgrupper innenfor eksempel antihypertensiva, antiastmatika, perorale antidiabetika og antibiotika. Interessant nok kan det være holdepunkter for at metaanalysebaserte effektstørrelser for antipsykotika representerer underestimater. Disse bygger hovedsakelig på randomiserte, kontrollerte dobbeltblindede studier preget av høyselekterte pasientutvalg med lang sykehistorie, som er assosiert med dårligere behandlingsrespons. Eksempelvis var gjennomsnittlig sykdomsvarighet i nevnte metaanalyse 14 år (1). Studier med mer representative pasientutvalg finner betydelig større symptomreduksjon. I den åpne, randomiserte EUFEST-studien fant man $60 \%$ symptomreduksjon versus $40 \%$ i tradisjonelle RCTer ved førsteepisode psykose (3). Robinson og medarbeidere (4) fant i deres naturalistiske oppfølging av førsteepisodepasienter at $87 \%$ responderte på behandling i løpet av det første året, med 9 ukers median tid til respons. Pasientene ble behandlet i henhold til en standardisert algoritme, der også klozapin inngikk.

I vedlikeholdsbehandling har antipsykotika vist betydelig reduksjon av risiko for psykotiske tilbakefall sammenlignet med placebo (5). Om behandlingen ble bråseponert eller gradvis trappet ned, påvirket ikke resultatene (5).

Oppsummert er antipsykotika effektive, og det store flertallet kan forvente behandlingsrespons. Det finnes en undergruppe pasienter uten sikker effekt av medikamentene, men disse er inntil videre ikke mulig å identifisere før behandling er utprøvd.

\section{Erik Johnsen}

erik.johnsen@helse-bergen.no

Erik Johnsen (f. 1973) er assisterende avdelingssjef og overlege ved Haukeland universitetssykehus og professor II ved Universitetet i Bergen.

Ingen oppgitte interessekonflikter.

\section{Litteratur}

1. Leucht S, Cipriani A, Spineli L et al. Comparative efficacy and tolerability of 15 antipsychotic drugs in schizophrenia: a multiple-treatments meta-analysis. Lancet 2013; 382: 951-62.

2. Leucht $S$, Hierl S, Kissling W et al. Putting the efficacy of psychiatric and general medicine medication into perspective: review of meta-analyses. $\mathrm{Br} \mathrm{J}$ Psychiatry 2012: 200: 97-106

3. Kahn RS, Fleischhacker WW, Boter $\mathrm{H}$ et al; EUFEST study group. Effectiveness of antipsychotic drugs in first-episode schizophrenia and schizophreniform disorder: an open randomised clinical trial. Lancet 2008; 371: 1085-97.

4. Robinson DG, Woerner MG, Alvir JM et al. Predictors of treatment response from a first episode of schizophrenia or schizoaffective disorder. Am J Psychiatry 1999: 156: 544-9

5. Leucht S, Tardy M, Komossa K et al. Maintenance treatment with antipsychotic drugs for schizophrenia. Cochrane Database Syst Rev 2012; 5: CD008016.

\section{Re: Psykiatriens indre konflikter eksponert}

Tor Ketil Larsen demonstrerer i sin kommentar om medikamentfri behandling en bedrevitende arroganse som ripper opp i smertefulle minner fra min tid som psykiatrisk pasient. Det gjør vondt å være vitne til den tilsynelatende totale mangelen på respekt for pasienters erfaringskompetanse og medbestemmelsesrett som Larsen fremviser. Den nedlatende og paternalistiske holdningen til Larsen er dessverre fremdeles ganske gjengs blant endringsresistente psykiatere. Heldigvis er ikke alle fagfolk like umusikalske som Larsen. Heldigvis er ikke alle fagfolk like kunnskapsløse om bakgrunnen for tilblivelsen av medikamentfrie behandlingsplasser som ham.

Larsen har rett $\mathrm{i}$ at det er vanskelig å identifisere ikke-responderne prospektivt. Det er imidlertid mye som tyder på at viljen til å indentifisere ikke-respondere retrospektivt er mangelfull og vilkårlig i mainstream psykiatri. Min erfaring er at psykosepasienter som ikke har ønsket effekt av psykofarmaka slett ikke alltid får trappe ned eller seponere slik Larsen hevder; vi får i stedet høyere doser, ikke sjelden langt over anbefalingene, og altfor ofte i medikamentcocktails som det ikke finnes fnugg av vitenskapelig belegg for å bruke på levende mennesker. Protesterer vi, nedtegnes det i journal at vi er lite samarbeidsvillige og mangler sykdomsinnsikt, og så får vi medikamentene på tvang i stedet. Argumenterer vi saklig for at vi har prøvd dette før, med dårlig resultat, får vi en diagnose til. Dette er virkeligheten vi som ønsker oss medikamentfrie behandlingsplasser, står i. Å underkjenne eller bortforklare dette med at dere ikke kjenner dere igjen i vår virkelighetsbeskrivelse (som er gjengangeren vi møtes med, både i klinikk og i avisspalter) er et hån mot mennesker som virkelig fortjener bedre.

Jeg vet ikke om jeg skal le eller gråte når pasientorganisasjoner jeg er medlem av, blir beskyldt for å manipulere helseministeren til å fatte beslutninger som vil frarøve pasienter rett til behandling i tråd med retningslinjene. Det er kanskje stygt av meg å le, men det er unektelig en smule komisk når Larsen nærmest fremstiller det som om tilgangen på behandlingsplasser med psykofarmakologisk behandling blir truet av at det endelig opprettes en håndfull medikamentfrie sengeposter i hver helseregion.

Ja visst er mennesker med psykoseerfaringer en sårbar gruppe, men kom ikke og fortell oss at vi ikke evner å stå på barrikadene! Sårbarheten vår handler ikke om at vi mangler «tilbud» om psykofarmakologisk behandling. Den handler først og fremst om at muligheten til å takke nei til psykofarmaka ikke er lovfestet, at det brukes altfor mye tvang og at det fremdeles er psykiatere som har makta og alle midlene i møtet med både nye og garvede, kompetente pasienter.

Pasienter som får komme til medikamentfrie avdelinger, har tatt et valg basert på erfaringer eller kunnskap som Larsen ikke bør stille seg til doms over. Definisjonen på god behandling handler ikke om medikamenteffektstudier med diskutabelt design. Til syvende og sist må det være opp til den enkelte pasient å vurdere hvorvidt behandlingen oppleves som nyttig eller ikke. Endelig får vi non-respondere et tilbud vi har bedt om i flere tiår. Det er forunderlig at det har skapt slik furore.

\section{Merete Nesset}

meretesmetode@gmail.com

Merete Nesset (f. 1963) er student.

Ingen oppgitte interessekonflikter. 